\title{
Perilaku Harian Buaya Muara (Crocodylus porosus, Schneider 1801) di Pusat Penyelamatan Satwa Jogja
}

\section{Daily Behaviour of Saltwater Crocodile (Crocodylus porosus, Schneider 1801) in Jogja Animal Rescue Center}

\author{
Purwo Setio I. ${ }^{1}$, A. Fanani Muharromi ${ }^{2}$, Subekti Prihantono ${ }^{2}$, Tony Febri Qurniawan ${ }^{2}$, A. \\ Prima Nugraha ${ }^{2}$, dan Rury Eprilurahman ${ }^{3}$ \\ ${ }^{1}$ Pusat Penyelamatan Satwa Jogjakarta, Sedangsari, Pengasih, Kulonprogo, Yogyakarta \\ ${ }^{2}$ Kelompok Studi Herpetologi, Fakultas Biologi Universitas Gadjah Mada Yogyakarta \\ ${ }^{3}$ Laboratorium Taksonomi Hewan, Fakultas Biologi Universitas Gadjah Mada Yogyakarta \\ E-mail: tonie_kun@yahoo.com; ap.nugraha@yahoo.com *Penulis untuk korespondensi
}

\begin{abstract}
The aim of this research was to find out the daily behaviour of Crocodylus porosus in Jogja Animal Rescue Center (PPSJ). The daily behaviour included feeding habit, social behaviour, basking and movement. This research was using Focal Animal Sampling Method and observed for four months. As individual targets were male and female dominant of $C$. porosus, Monti and Bunda. The Runs test showed that the behavior of $C$. porosus had a pattern in daily activities. Based on Mann-Whitney $U$ test, both male and female of $C$. porosus did not have any difference in feeding habit $\left(U=16 ; n_{1}=6 ; n_{2}=6 ; p>0,05\right)$, social behaviour $\left(U=29 ; n_{1}=8 ; n_{2}=8 ; p>0,05\right)$, basking $\left(U=12 ; n_{1}=5 ; n_{2}=5 ; p>0,05\right)$ and movement $\left(U=16 ; n_{1}=6 ; n_{2}=6 ; p>0,05\right)$.
\end{abstract}

Key words: Behaviour, daily activity, Crocodylus porosus, Monti and Bunda, PPSJ

\begin{abstract}
Abstrak
Penelitian ini bertujuan mengetahui perilaku harian buaya muara (Crocodylus porosus) di Pusat Penyelamatan Satwa Jogja. Perilaku harian yang diamati meliputi kebiasaam makan, perilaku sosial, berjemur, dan pergerakan. Penelitian ini menggunakan metode Focal Animal Sampling dan diamati selama empat bulan. Objek yang diamati dalam penelitian ini adalah buaya muara (Crocodylus porosus) jantan dan betina dominan. Berdasarkan hasil tes Runs yang telah dilakukan menunjukkan bahwa perilaku Crocodylus porosus membentuk pola aktifitas harian. Sedangkan berdasarkan uji U Mann-Whitney menunjukkan bahwa kedua buaya tersebut (jantan maupun betina) tidak memiliki perbedaan dalam kebiasaan makan $\left(U=16 ; \mathbf{n}_{1}=6 ; \mathbf{n}_{2}=6\right.$; $p>0,05)$, perilaku sosial $\left(U=29 ; n_{1}=8 ; n_{2}=8 ; p>0,05\right)$, basking $\left(U=12 ; n_{1}=5 ; n_{2}=5 ; p>0,05\right)$ dan pergerakan $\left(U=16 ; n_{1}=6 ; n_{2}=6 ; p>0,05\right)$.
\end{abstract}

Kata kunci: Perilaku, aktifitas harian, Crocodylus porosus, Monti dan Bunda, PPSJ

Diterima: 12 Agustus 2009, disetujui: 10 Juni 2010

\section{Pendahuluan}

Crocodylus porosus atau disebut juga buaya muara merupakan salah satu dari tujuh jenis buaya yang hidup di Indonesia. Buaya jenis ini tersebar di seluruh perairan Indonesia mulai dari Pulau Sumatra hingga Pulau Irian Jaya (Iskandar, 2000). Secara morfologi, Neil (1946) dan Weeb et al., (1978) dalam Gans (1985) mengatakan bahwa pada individu dewasa warna tubuh buaya muara lebih gelap daripada saat masih remaja. Bagian ventral tubuhnya berwarna kuning gading kecuali di bagian ekor yaitu abuabu. Ukuran maksimal pada individu jantan mampu mencapai 5-6 m, sedangkan individu betina memiliki kisaran 2,5-3 m. Kematangan seksual pada buaya muara biasanya dicapai pada umur 10 tahun. Individu jantan mampu mencapai ukuran tubuh kurang lebih $3,2 \mathrm{~m}$. Berbeda dengan individu jantan, individu betina memiliki ukuran tubuh yang lebih kecil pada saat matang seksual yaitu kurang lebih 2,2 m. 
Habitat buaya muara umumnya di wilayah perairan payau, tetapi terkadang juga ditemukan di sungai air tawar dan rawa (Britton, 2002). Saat ini buaya muara semakin sulit ditemukan hidup di alam bebas. Berdasarkan data IUCN (2008) populasinya di dunia terus menurun dan dimasukkan kedalam satwa yang terancam punah, sedangkan berdasarkan CITES tergolong Apendiks I. Di Indonesia, perburuan dan eksploitasi buaya muara dari alam telah dilarang oleh Pemerintah dan Negara melalui PP No.7 dan 8 tahun 1999. Penelitian serta usaha penyelamatan telah giat dilakukan dalam rangka mencegah punahnya buaya ini, salah satunya adalah penelitian mengenai perilaku buaya.

Buaya muara merupakan salah satu jenis reptil yang memiliki perilaku unik dan menarik. Perilaku buaya dan jumlah individu dalam suatu populasi dapat berpengaruh terhadap pertumbuhan buaya itu sendiri (Britton, 2002; Poletta et al., 2008). Tiap perilaku buaya dipengaruhi oleh faktor kenyamanan habitat yang merupakan tempat buaya berinteraksi dengan lingkungannya. Terdapat dua macam lingkungan yaitu alam bebas dan buatan manusia seperti penangkaran. Pada dua habitat yang berbeda tersebut salah satu perilaku buaya yang terpengaruh pada umumnya adalah keaktifan buaya itu sendiri. Oleh karena itu, mempelajari dan mengamati perilaku harian buaya muara di penangkaran sangat menarik untuk diteliti guna memberikan informasi kepada pihak terkait dalam memberikan kebijakan perawatan satwa buaya muara yang lebih baik. Dalam tahap ini yang dipelajari adalah pola perilaku buaya jantan dominan (Monti) dan betina dominan (Bunda) yang terdapat di Pusat Penyelamatan Satwa Jogja.

\section{Metode Penelitian}

\section{Lokasi dan Waktu Penelitian}

Penelitian ini dilakukan pada bulan Maret-Juni 2007 di kandang buaya Pusat Penyelamatan Satwa Jogja. Sebelum dilakukan pengamatan perilaku, terlebih dahulu dilakukan pengamatan inisiasi selama tiga hari untuk menentukan jenis perilaku yang akan diamati dan waktu pengamatan. Pengamatan dilakukan pada pagi, siang, sore, dan malam hari.

\section{Pengambilan Data}

Metode yang digunakan adalah metode deskriptif dengan teknik Focal Animal Sampling (Altman, 1973). Obyek yang diamati adalah seekor buaya jantan dominan yang bernama Monti dan seekor buaya betina dominan yang bernama Bunda. Perilaku keduanya masingmasing dicatat tiap menit. Data yang diambil adalah data perilaku berjemur/istirahat, perilaku sosial, bergerak dan kebiasaan makan serta data parameter lingkungan berupa suhu udara.

Analisis data perilaku harian dilakukan secara deskriptif dan analisis statistik nonparametrik (Siegel, 1992) menggunakan uji statistik U Mann-Whitney dan Runs. Uji statistik U Mann-Whitney dilakukan untuk mengetahui apakah frekuensi perilaku harian Monti dan Bunda memiliki frekuensi perilaku yang sama ataukah berbeda. Uji statistik Runs dilakukan untuk mengetahui apakah kejadian perilaku yang dilakukan merupakan kejadian yang bersifat kebetulan dan acak ataukah membentuk suatu pola perilaku harian tertentu.

\section{Hasil dan Pembahasan}

Pada bulan Maret-Juni 2007 telah dilakukan pengamatan perilaku Monti (buaya jantan dominan) dan Bunda (buaya betina dominan) meliputi perilaku berjemur/istirahat, sosial, bergerak dan kebiasaan makan. Berikut ini merupakan tabel persentase perilaku harian. Monti dan Bunda.

Jumlah total waktu pengamatan Monti sebanyak 46.690 menit, sedangkan Bunda sebanyak 44.560 menit. Perilaku yang banyak terlihat pada Monti adalah bergerak, berjemur/istirahat, sosial dan makan. Adapun perilaku yang dilakukan Bunda berturut-turut adalah bergerak, berjemur/istirahat, makan dan sosial.

Dari Tabel 1 juga dapat dilihat bahwa untuk Monti lebih banyak melakukan perilaku sosial daripada makan sedangkan Bunda lebih banyak makan daripada memperlihatkan perilaku sosial. Hal tersebut disebabkan Monti merupakan jantan dominan sehingga dominasinya akan tampak terlihat dalam perilaku sehari-harinya, sedangkan Bunda walaupun juga termasuk dalam betina dominan 
tetapi dominasi dari betina dominan cenderung terlihat saat pemilihan letak sarang untuk menempatkan telurnya, pada saat penelitian belum memasuki saat perkembangbiakan buaya sehingga dominasi buaya betina dominan cenderung tidak terlihat.

Berdasarkan uji statistik U Mann-Whitney tidak terdapat perbedaan aktivitas perilaku berjemur/istirahat, sosial, bergerak dan kebiasaan makan antara Monti dan Bunda. Meskipun terbukti tidak terdapat perbedaan frekuensi perilaku berjemur/istirahat, sosial, bergerak dan kebiasaan makan di antara keduanya, hasil uji statistik Runs menunjukkan bahwa frekuensi perilaku yang dilakukan keduanya membentuk suatu pola perilaku harian tertentu.

\section{Parameter Lingkungan}

Parameter fisik yang diukur berupa suhu lingkungan disajikan pada Tabel 2. Pada dasarnya suhu lingkungan menjadi variabel dominan yang berpengaruh terhadap pola dan frekuensi perilaku harian buaya (Pérez dan Escobedo-Galvánn, 2009). Suhu berpengaruh sebagai faktor pembatas dan reproduksi serta mengatur aktivitas enzim dalam metabolisme, khususnya nafsu makan dan proses pencernaan (Piña dan Larriera, 2002). Perubahan suhu yang besar akan menyebabkan perubahan pada pola perilaku buaya. Berdasarkan Tabel 2, suhu rerata tertinggi terukur pada bulan Juni yaitu $29,5^{\circ} \mathrm{C}$, sedangkan suhu terendahnya yaitu $28^{\circ} \mathrm{C}$. Suhu yang tinggi pada bulan Juni menyebabkan frekuensi perilaku buaya menjadi lebih banyak di perairan daripada di daratan.

\section{Perilaku Bergerak}

Perilaku bergerak berhubungan erat dengan keadaan lingkungan dan juga ketahanan tubuh karena perilaku bergerak mempunyai dampak langsung terhadap kemampuan menangkap mangsa, kemampuan untuk menjelajah dan juga perilaku sosial pada binatang (Elsworth et al., 2003; Soendjoto et al., 2006).

Hasil penelitian yang dilakukan terlihat melalui uji $U$ Mann Whitney $\left(U=16 ; \mathrm{n}_{1}=6\right.$; $\left.\mathrm{n}_{2}=6 ; \mathrm{p}>0,05\right)$ bahwa tidak terdapat perbedaan frekuensi perilaku bergerak pada jenis kelamin yang berbeda. Berikut tabel frekuensi perilaku bergerak Monti dan Bunda (Tabel 3).

Tabel 1. Frekuensi perilaku harian Monti dan Bunda (dalam \%).

\begin{tabular}{lcccc}
\hline \hline Individu & Bergerak & Berjemur/Istirahat & Makan & Sosial \\
\hline \hline Monti & 88,41 & 7,37 & 1,54 & 2,68 \\
Bunda & 92,21 & 5,03 & 1,46 & 1,3 \\
\hline \hline
\end{tabular}

Tabel 2. Parameter rata-rata suhu udara dari bulan Maret-Juni 2007 (dalam ${ }^{\circ} \mathrm{C}$ ).

\begin{tabular}{ccccc}
\hline \hline Minggu ke & Maret & April & Mei & Juni \\
\hline \hline I & 28 & 28 & 28,5 & 29,5 \\
II & 28 & 28,5 & 29 & 28 \\
III & 28.5 & 29 & 28,5 & 29,5 \\
IV & 28,5 & 28,5 & 29 & 29 \\
\hline \hline
\end{tabular}

Tabel 3. Frekuensi perilaku bergerak Monti dan Bunda (dalam \%).

\begin{tabular}{|c|c|c|c|}
\hline No. & Jenis Perilaku & Monti & Bunda \\
\hline 1 & Berenang & 24,2 & 18,86 \\
\hline 2 & Menyelam & 35,2 & 38,7 \\
\hline 3 & Ambil nafas & 40,41 & 42,25 \\
\hline 4 & High walk & 0 & 0 \\
\hline 5 & Galloping & 0 & 0,05 \\
\hline 6 & Belly crawl & 0 & 0,12 \\
\hline 7 & Belly run & 0,2 & 0.02 \\
\hline
\end{tabular}


Pengamatan terhadap perilaku bergerak buaya dibedakan dalam dua macam perilaku yang berbeda, yaitu perilaku bergerak yang dilakukan di perairan dan perilaku bergerak di daratan. Hal ini disebabkan buaya merupakan hewan yang bersifat semi-akuatik. Pada hewan yang bersifat semi-akuatik dalam kesehariannya selain berada di lingkungan perairan juga sering berada di lingkungan daratan. Di antara kedua lingkungan tersebut perilaku buaya di perairan lebih penting daripada perilaku bergerak di daratan karena berbagai macam kebiasaan buaya seperti menangkap mangsa, reproduksi, dan interaksi sosial terjadi di dalam air.

Berdasarkan hasil penelitian, frekuensi perilaku bergerak di perairan yang paling sering dilakukan adalah mengambil nafas/muncul kepermukaan air. Proses pernafasan pada buaya sangat khas karena dipengaruhi oleh struktur jantungnya (Farmer dan Carrier, 2000). Dengan perilaku sering mengambil nafas/muncul kepermukaan air maka konsumsi oksigen $\left(\mathrm{O}_{2}\right)$ akan meningkat sehingga penghasilan panas internal juga akan meningkat. Hal tersebut menunjukkan bahwa buaya yang sudah dewasa memiliki tingkat metabolisme yang tinggi. Selain itu kemungkinan perilaku sering mengambil nafas atau muncul ke permukaan air juga berguna untuk menghemat energi yang digunakan serta untuk mengurangi panas yang berlebih (Piña dan Larriera, 2002).

Dari pegamatan ternyata buaya Monti akan berenang dengan bagian tubuh dorsalnya terlihat, kemungkinan ini merupakan perilaku dominansi supaya jantan lain mundur dari hadapan jantan dominan tersebut. Kecepatan berenang pada buaya juga akan meningkat seiring dengan bertambahnya panjang tubuh buaya (Elsworth et al., 2003). Selain itu juga berhasil diamati lamanya menyelam buaya dominan selama pengamatan paling lama adalah 80 menit. Adapun untuk perilaku bergerak di darat yang sering digunakan adalah belly run. Hal ini disebabkan pada buaya dominan memiliki ukuran tubuh yang besar dan berat sehingga tidak terlalu sering mengangkat tubuhnya.

\section{Perilaku Makan}

Hasil penelitian yang dilakukan terlihat melalui uji $U$ Mann Whitney $\left(U=16 ; n_{1}=6 ; n_{2}=6\right.$; $\mathrm{p}>0,05)$ bahwa tidak terdapat perbedaan frekuensi perilaku makan antara Monti dan Bunda.Penjelasan rinci frekuensi perilaku makan Monti dan Bunda disajikan dalam dalam Tabel 4.

Buaya memiliki otak paling berkembang dibandingkan reptil lainnya. Mereka dapat mempelajari pola dan kebiasaan mangsa (Morpurgo et al., 1993). Pada buaya dewasa kemampuan ini telah berkembang sehingga Monti dan Bunda dapat mengingat jam makan mereka. Pemberian pakan dengan treatment rutin akan menyebabkan buaya menjadi terbiasa untuk tidak menangkap mangsanya dengan strategi tertentu. Pemberian pakan aritmik bertujuan agar buaya tidak mengingat kapan ia akan diberi makan sehingga buaya terbiasa hidup mencari makan dengan oportunis seperti saat di habitat alaminya.

Dari jenis makanan yang dimakan, ternyata untuk Bunda lebih aktif mencari makan dari pada Monti, dengan memakan kelelawar yang banyak terbang di sekitar kandang, ikan dan katak. Perilaku Bunda saat makan ternyata juga lebih sering dengan strategi menerkam tibatiba mangsanya di perairan. Bunda menunggu mangsa dalam air dan berkamuflase dengan mata telinga dan nostril tetap di permukaan air lalu menerkam mangsa ketika lengah untuk kemudian ditarik masuk ke dalam air hingga tenggelam. Pada Monti strategi memangsanya dengan menyelam dan menerkam tiba-tiba, lalu mangsa di lempar ke udara (dengan bantuan gravitasi) dan perlahan mangsa pun ditelan. Gigi yang tajam, otot perut dan asam pencernaan yang kuat membuat buaya tidak perlu menguyah makanannya.

Jenis pakan yang diberi oleh pihak PPSJ antara lain yaitu ayam dan itik. Pada saat pemberian pakan, terlihat bahwa jantan dominan mendapatkan kesempatan makan pertama kali. Monti selalu terlihat menyerang buaya yang berusaha mendekati sumber makanan.

\section{Perilaku Berjemur/Istirahat}

Hasil penelitian yang dilakukan terlihat melalui uji $\mathrm{U}$ Mann Whitney ( $\mathrm{U}=12 ; \mathrm{n}_{1}=5 ; \mathrm{n}_{2}=5$; $\mathrm{p}>0,05)$ bahwa tidak ada perbedaan frekuensi perilaku berjemur/istirahat antara Monti dan Bunda. Penjelasan frekuensi perilaku berjemur/ istirahat Monti dan Bunda disajikan dalam Tabel 5. 
Buaya merupakan hewan yang bersifat ektotermik dan poikilotermik sehingga berjemur merupakan hal yang mutlak dilakukan oleh buaya untuk mengoptimalkan metabolisme dan mengintegrasikan antara lingkungan, perilaku, dan fungsi seluler supaya dapat berjalan semestinya (Cooper, 2002; Soendjoto et al., 2006). Buaya mendapatkan panas yang berasal dari lingkungan dengan tiga mekanisme yaitu radiasi, konveksi dan konduksi. Lamanya berjemur dari tiap-tiap jenis akan berbeda. Hal tersebut berkaitan dengan ukuran tubuh serta suhu lingkungan saat itu. Selain itu, terdapat perbedaan suhu tubuh pada saat menyelam dalam air dan pada saat melakukan berjemur. Pada saat menyelam suhu tubuh adalah $22-26^{\circ} \mathrm{C}$ sedangkan apabila melakukan aktivitas basking/berjemur suhu tubuhnya dapat mencapai 40-45 ${ }^{\circ} \mathrm{C}$ (Seebacher dan Murray, 2007). Untuk buaya yang berukuran besar tentu saja akan membutuhkan waktu berjemur yang lebih lama.

Perilaku berjemur buaya umumnya dilakukan di daratan dan apabila telah mendapatkan panas tubuh yang cukup akan kembali ke perairan untuk mengurangi panas yang berlebih. Selain itu dapat juga dengan cara membuka rahangnya. Buaya meningkatkan suhu tubuh dengan cara mengalirkan darah melalui kulit yang telah hangat supaya membawa panas ke pusat tubuh (Ross, 1989).

Berdasarkan hasil pengamatan perilaku berjemur, dapat dilihat bahwa perilaku berjemur atau istirahat pada buaya dominan yang ada di PPSJ lebih sering dilakukan di permukaan air. Hal tersebut disebabkan sebagian besar tepian kandang sebelah barat yang biasanya digunakan untuk berjemur buaya banyak ditumbuhi oleh putri malu (Mimosa sp.), pisang (Musa sp.) dan kersen (Muntingia sp.) sehingga lokasi tersebut tidak dapat digunakan untuk berjemur.

\section{Perilaku Sosial}

Hasil penelitian yang dilakukan terlihat melalui uji $U$ Mann Whitney $\left(\mathrm{U}=29 ; \mathrm{n}_{1}=8\right.$; $\left.\mathrm{n}_{2}=8 ; \mathrm{p}>0,05\right)$ bahwa tidak terdapat perbedaan frekuensi perilaku sosial pada jenis kelamin yang berbeda. Berikut Tabel frekuensi perilaku sosial Monti dan Bunda.

Buaya memiliki suatu hierarki dominansi baik itu populasi yang terdapat di alam liar maupun populasi yang terdapat di dalam penangkaran. Suatu individu yang dominan ditentukan dari ukuran dari buaya tersebut. Apabila buaya tersebut memiliki ukuran yang paling besar, individu buaya tersebut merupakan individu buaya yang paling dominan (Morpurgo et al., 1993). Individu jantan yang dominan memiliki kekuasaan dalam mengontrol kesempatan kawin, perolehan makanan dan ruang gerak, sedangkan individu betina cenderung memperlihatkan dominansinya saat melakukan pemilihan letak sarang (Ross, 1989).

Berdasarkan pengamatan dapat dilihat bahwa baik Monti maupun Bunda perilaku sosial yang paling besar frekuensinya adalah dominansi. Hal ini ditunjukkan dengan adanya perkelahian. Perkelahian pada buaya dapat terjadi ketika dalam wilayah kekuasaan buaya dominan tersebut dimasuki oleh buaya lain. Hanya individu tertentu yang boleh masuk wilayahnya. Dari hasil pengamatan ada saatnya buaya menyendiri, karena menjaga wilayahnya atau kalah dalam persaingan.

Dari hasil pengamatan juga tercatat Monti dan Bunda beberapa kali melakukan vokalisasi pendek. Diperkirakan vokalisasi tersebut untuk menggertak serta untuk memanggil anaknya. Perilaku sosial berupa vokalisasi memanggil anaknya serta menjaga sarang menunjukkan parental care yang dilakukan oleh Bunda.

Tabel 4. Frekuensi perilaku makan Monti dan Bunda (dalam \%).

\begin{tabular}{lcc}
\hline \hline Jenis Perilaku & Monti & Bunda \\
\hline \hline Berburu dengan & & \\
Diam di permukaan & 0 & 0 \\
Menyelam & 20,83 & 25,81 \\
Menerkam tiba-tiba & 20,83 & 30,65 \\
Menerkam di & & \\
Bagian kepala & 16,67 & 14,52 \\
Bagian ekstremitas & 0 & 0 \\
Tempat makan di & 20,83 & 0 \\
Daratan & 20,83 & 29,03 \\
Perairan &
\end{tabular}


Tabel 5. Frekuensi perilaku berjemur/istirahat Monti dan Bunda (dalam \%).

\begin{tabular}{ccc}
\hline Jenis Perilaku & Monti & Bunda \\
\hline \hline Tempat berjemur di & 52,38 & 58,93 \\
Permukaan air & 4,46 & 0,89 \\
Bawah kanopi & 19,64 & 4,46 \\
Tanah terbuka & 0 & 0 \\
Kegiatan dengan & 0 & 35,71 \\
Membuka mulut & 23,51 & \\
Menutup mulut
\end{tabular}

Tabel 6. Frekuensi perilaku sosial Monti dan Bunda (dalam \%).

\begin{tabular}{lcc}
\hline \hline \multicolumn{1}{c}{ Jenis Perilaku } & Monti & Bunda \\
\hline Intraspesifik & 8 & \\
Berkelahi & 12,8 & 0 \\
Vokalisasi & 66,4 & 8,78 \\
Dominansi & 4,8 & 43,86 \\
Menjaga sarang & 0 & 22,8 \\
Menjaga anak & & 17,54 \\
Dengan manusia & 0 & 7 \\
Menyerang & 4,8 & 0 \\
Lari/menghindar & 3,2 & 0 \\
Diam & & \\
\hline \hline
\end{tabular}

\section{Simpulan dan Saran}

\section{Simpulan}

Dari hasil penelitian dapat disimpulkan bahwa perilaku buaya dominan memperlihatkan perilaku yang lebih kompleks. Selain itu ternyata tidak terdapat perbedaan perilaku harian antara buaya jantan dominan dan betina dominan. Beberapa pola perilaku yang dilakukan buaya jantan dominan yaitu bergerak, berjemur/istirahat, sosial dan makan. Adapun pola perilaku buaya betina dominan yaitu bergerak, berjemur/istirahat, makan, dan sosial.

\section{Saran}

Pada penelitian selanjutnya perlu dilakukan pengamatan perilaku berbiak buaya yaitu antara bulan September sampai Januari. Selain itu juga perlu diteliti perilaku pada buaya juvenil dan remaja supaya dapat dipelajari perkembangan dan perbedaan perilaku buaya berdasarkan usia.

\section{Ucapan Terima Kasih}

Ucapan terima kasih dan penghargaan yang tinggi kepada Sugihartono selaku direktur
PPSJ, Kholis Munawar dan Didik R. selaku pengurus PPSJ serta kepada rekan-rekan Kelompok Studi Herpetologi (Onny N., Mahardika S.H., Marhani Hasna P., Tyas, I.G.A. Ayu Ratna P., Faiz Amali, Rizki Eka S.) atas segala bantuan dan dukungan.

\section{Daftar Pustaka}

Altmann, H. 1973. Observational Study of Behavior: Sampling Methods. Behavior, 49: 227-267.

Britton, A. 2002. Crocodylus Porosus (Scneider, 1801). http://www.flmnh.ufl.edu/cnch/csp-cpor.htm. 27/05/2008.

Cooper, K.E. 2002. Molecular Biology of Thermoregulation: Some Historical Perspectives on Thermoregulation. J. Appl. Physiol., 92: 1717-1724.

Elsworth, G.F., Seebacher, F. dan Franklin, C.E. 2003. Sustained Swimming Performing in Crocodiles (Crocodylus porosus): Effects of Body Size and Temperature. J. of Herpetology, 37: 363-368.

Farmer, C.G. dan Carrier, D.R. 2000. Respiration and Gas Exchange During Recovery from Exercise in the American Alligator. Short Communication. Respiration Physiology, 120: 81-87.

Gans, C. 1985. Biology of Reptilia. John Wiley \& Sons, Inc.: New York. Pp 335-344. 
Iskandar, D.T. 2000. Kura-kura \& Buaya Indonesia \& Papua Nugini. PALMedia Citra. Bandung. Pp. 157-159.

IUCN. 2008. Red list of Threatened Species. http://www. iucnredlist.org. 27/05/2008.

Morpurgo, B., Gyaryahu, G. dan Robinzon, B. 1993. Aggressive Behaviour in Immature Captive Nile Crocodiles, Crocodylus Niloticus, in Relation to Feeding. Physiology \& Behavior, 53 (6): 1157-1161.

Neill, W.T. 1946. Notes on Crocodylus novae-guineae. Copeia. 1: 17-20.

Pérez, O. dan Escobedo-Galánn, A.H. 2009. Potential Effects of El Niño-South Oscillation (ENSO) on Growth of the American Crocodile, Crocodylus Acutus (Crocodylia: Crocodilydae) in Captivity. J. of Thermal Biology, 34: 14-16.

Piña, C. dan Larriera, A. 2002. Caiman Latirostris Growth: the Effect of a Management Technique on the Supplied Temperature. Short Communication. Aquaculture, 211: 387-392.
Poletta, G.L., Larriera, A. dan Siroski, P.A. 2008. Broad Snouted Caiman (Caiman Latirostris) Growth Under Different Rearing Densities. Short Communication. Aquaculture, 280: 264-266.

Ross, C.A. 1989. Crocodiles and Alligators. Facts on Files. New York. Pp. 76-153.

Seebacher, F. dan Murray, S.A. 2007. Transient Receptor Potential Ion Channels Control Thermoregulatory Behaviour in Reptiles. Plos One, 2 (3): e281.

Siegel, B. 1992. Statistik Non-parametrik untuk Ilmu-Ilmu Sosial. PT. Gramedia Utama. Jakarta.

Soendjoto, M.A., Hadi, S.A., Muhammad, B. dan Heru, S. 2006. Aktivitas Harian Bekantan (Nasalis larvatus wurmb) di Hutan Karet Kabupaten Tabalong, Kalimantan Selatan. Biota, XI (2): 101-109.

Weeb, G.J.W., Hollis, G.J. dan Manolis, S.C. 1991. Feeding Growth, and Food Conversion Rates of Wild Juvenile Saltwater Crocodiles (Crocodylus porosus). J. of Herpetology, 25: 460-470. 